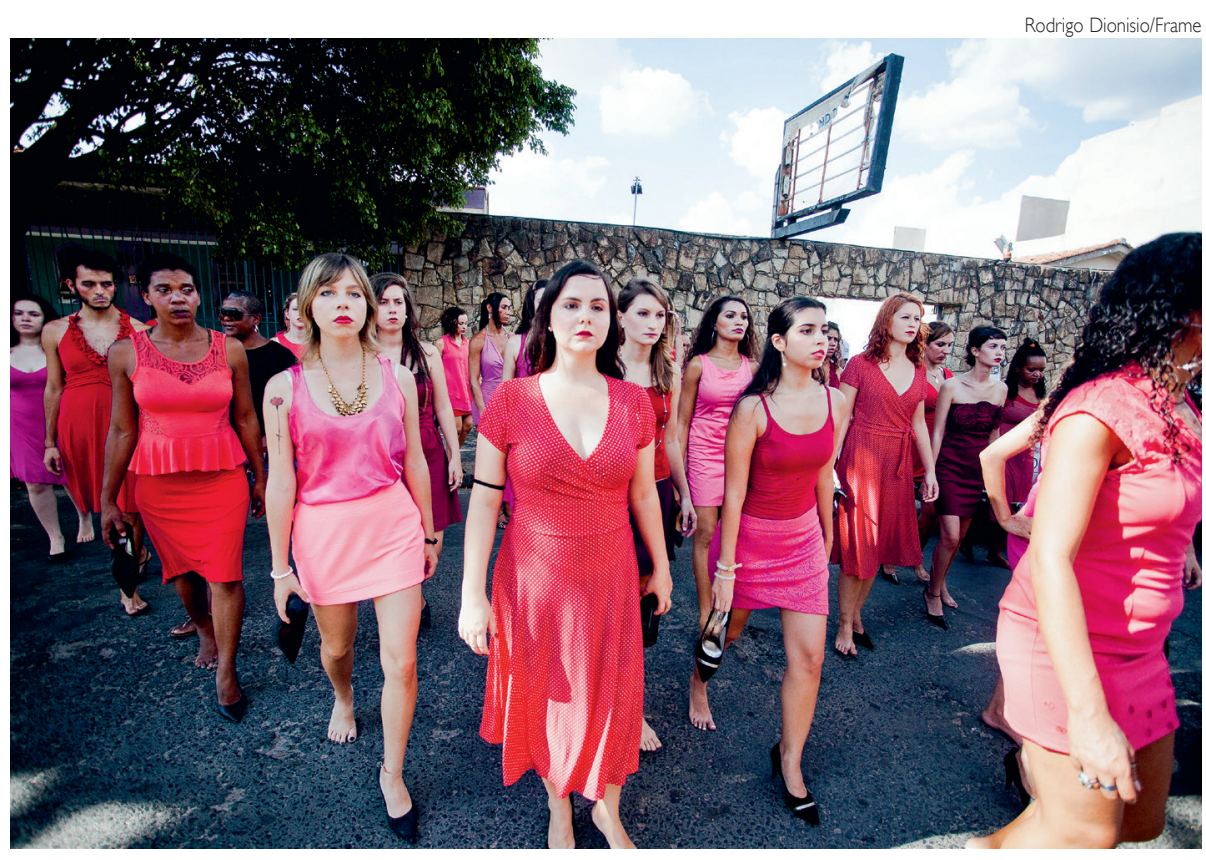

Intervenção urbana Entre saltos

INTERVENÇÃO URBANA

\title{
ARTISTAS OCUPAM ESPAÇOS URBANOS E INTERAGEM DE FORMA CRIATIVA
}

É na rua que a maioria das intervenções urbanas acontece. Não existe plateia. As pessoas não compram ingresso e não se sentam em uma cadeira a espera de um espetáculo. A performance urbana é um tipo de apresentação que invade a vida das pessoas em seu cotidiano na cidade. "É tudo que foge do parâmetro artístico convencional", afirma Priscilla Toscano, atriz, pesquisadora e uma das diretoras do Coletivo PI, grupo que realiza intervençôes urbanas efêmeras utilizando diferentes linguagens, tais como a performance, teatro, dança e as artes visuais. Mas qual a diferença entre o teatro e a intervenção? $\mathrm{O}$ teatro é uma lingua- gem artística com um plano ficcional, um jogo com códigos já construídos entre fazedores e público: "está num espaço protegido e previamente compreendido", aponta Pâmella Cruz, que também dirige o Coletivo PI. "Com as intervençōes, queremos criar alguns estranhamentos, um impacto visual e poético nas situações do cotidiano", completa Priscilla. Segundo ela, a performance é influenciada pelas artes visuais, uma vez que as imagens são o grande norte dos trabalhos. "Queremos que as pessoas sejam impactadas pela potência da imagem e de sua poesia". O urbano é terreno fértil para a criação no campo das intervenções. 
"A rua é soberana, coloca desafios e possibilidades que vão muito além daquilo que podemos prever", constata Priscilla. "A intervenção urbana está no espaço cotidiano, na rotina, e provoca rupturas, dilata olhares, instaura novas maneiras de pensar o tempo e o espaço na dinâmica cotidiano", ressalta Pâmella. "O foco é pensar as dinâmicas da cidade, as relações entre nós, sujeitos urbanos, e os espaços que construímos e habitamos para, a partir daí, criar uma intervenção que ressalte determinados elementos, ativando zonas de memória, liberdade e jogo", explica. Para fazer performance urbana é preciso dominar a rotina do espaço público e traçar estratégias para interferir no trânsito, na avenida, na rua, na calçada, em um viaduto etc. Além disso, é preciso um olhar diferenciado sobre o espaço urbano, fonte de inspiração para o artista que opta pela intervenção.

ENTRE SALTOS Um dos trabalhos mais ousados que o Coletivo PI realizou foi a intervenção intitulada Entre saltos. Um coro de pessoas, em sua maioria mulheres, anda no meio da rua com roupas vermelhas e rosas, calçando um sapato de salto alto em um dos pés e levando o outro nas mãos. A ideia da performance surgiu depois que Priscilla Toscano viu uma mulher na Avenida Paulista, na cidade de São Paulo, andando com um sapato com salto quebrado na mão e outro no pé. "Eu pensei: por que ela não tira o sapato do pé e anda descalça? Levei essa imagem da mulher executiva para o grupo e, depois de experimentar essa sensação na rua, discutimos e construímos a intervenção por meio do diálogo com várias mulheres", conta a pesquisadora. "Entre saltos é um trabalho que se efetiva nesse encontro com tantas pessoas, que trazem sonhos, questionamentos, independente da classe social, de ser artista ou não", completa Pâmella.

A performance foi realizada em diversas cidades do Brasil. Em Campinas, interior de São Paulo, a apresentação contou com a parceria do Sesc, que, em 2014, juntamente com o Coletivo PI, organizou uma oficina com mulheres que trabalham e moram no Jardim Itatinga, bairro na periferia da cidade que concentra grande número de bares e casas de shows eróticos. Também participaram da intervenção estudantes de artes cênicas da Universidade Estadual de Campinas (Unicamp), travestis e o público em geral.

RUPTURAS NO COTIDIANO Priscilla acredita, diferentemente do teatro, que as mulheres que participam de uma intervenção urbana como Entre saltos, não estão disfarçadas e protegidas por uma personagem. "Cada mulher tem uma história diferente. É uma caminhada que vai além de proporcionar um momento artístico. São muitas emoções postas em evidência no momento da performance", considera a pesquisadora. Em dezembro de 2014, o Coletivo PI voltou ao bairro campineiro para exibir o documentário Entre saltos, que contou a trajetória da intervenção em todas as cidades pelas quais passou.

Priscilla Toscano também integra o Desvio Coletivo, rede de criadores em cena performativa que atua na zona de fronteira entre o teatro, a performance, a dança e as artes visuais e tecnológicas. A rede surgiu a partir de um projeto de pesquisa do Laboratório de Práticas Performativas, ligado à Escola de Comunicaçōes e Artes (ECA), da Universidade de São Paulo (USP). O Desvio Coletivo apresentou, em 2014, Cegos em várias cidades do país. Nesta intervenção, dezenas de homens e mulheres, em trajes sociais, cobertos de argila e de olhos vendados, caminham lentamente, com objetivo de interferir, de forma poética, no fluxo do cotidiano da cidade. Para Priscilla, uma das diretoras da intervenção, Cegos, faz uma crítica à condição massacrante do trabalho corporativo iconizado no terno e gravata usados pelos homens e no tailleur adotado pelas mulheres em toda grande metrópole. O título da ação é inspirado no quadro "A parábola dos cegos", do pintor belga Pieter Bruegel (1568), em que se veem cegos conduzindo cegos, cada qual tentando encontrar algum apoio para avançar pelo caminho. "Não importa se para quem está na rua, assistindo, a intervenção é entendida ou não como arte. O que importa é o incômodo que a performance causa", afirma.

Para Pâmella Cruz, as intervenções urbanas ajudam a pensar e a criar espaços de arte e afetividade no cotidiano da cidade. "Ao instaurar rupturas temporárias na rotina, elas instigam olhares curiosos, estimulam as pessoas a repensar relações e questionar normas e padrōes, reafirmam as ruas e a cidade como lócus da partilha, da convivência das diferenças, da experiência com outro, da criação de novas formas de habitar", finaliza.

Amanda Cotrim 